\title{
Structure and Process Evaluation of Cold Chain Management and Routine Immunization Services in Rural Western Gujarat
}

\author{
Pithadia Pradeep R, Shah Viral R, Makwana Naresh R*, Parmar Dipesh \\ Department of PSM, M P Shah Government Medical College, Jamnagar, India \\ *Corresponding Author: drnareshm@yahoo.com
}

Received: 3-7-2020

Revised: $15-8-2020$

Published: $31-8-2020$

Keywords:

Immunization

Cold chain

vaccine

\begin{abstract}
Maintenance of cold chain points are vital for preserving potency of vaccines for immunization of children and thereby averting vaccine preventable diseases in the community. Cold chain handlers should have sufficient knowledge and skills related to cold chain equipment handling and immunization practices. The present study aims to evaluate maintenance of cold chain facilities at primary health care centers (PHCs), related logistics and observation of Mamta Day (Immunization Day). The observations include knowledge and practice of health workers about immunization activities, their communication skills, training status etc. Methods: There are total 31 Primary Health Centers in Jamnagar district, out of which, we decided to include $50 \%$ (15) of primary health centers and observed their cold chain, and Immunization day at a subcentre or Anganwadi centre of the selected PHC to assess the quality of immunization services. We included equal number of cold chain points from each block of the district to make it representative of entire district. Results: Average population served by a cold chain point is 21985 . Vaccine related logistics like cold boxes, vaccine carriers etc. were adequate in all facilities. All cold chain equipments were placed as per standard guidelines. The posts of medical officers and pharmacists were vacant in almost one fourth of cold chain points and they were run on deputation from other facilities. The knowledge and skills of health workers related to immunization practices were found to be satisfactory. Conclusion: We observed that routine immunization program was implementing in the district satisfactorily. The posts of medical officers and pharmacists need to be filled up at the earliest for smooth functioning of immunization program in primary health centres.
\end{abstract}

Cite this article as: Pradeep R.P., Viral RS., Naresh RM., Dipesh, P. (2020) Structure and Process Evaluation of Cold Chain Management and Routine Immunization Services in Rural Western Gujarat. Journal of basic and applied Research in Biomedicine, 6(2): 70-74

\begin{tabular}{|c|c|}
\hline & $\begin{array}{l}\text { This work is licensed under a Creative Commons Attribution } 4.0 \text { License. You are free to copy, distribute and perform the work. You must attribute } \\
\text { the work in the manner specified by the author or licensor. }\end{array}$ \\
\hline
\end{tabular}

\section{INTRODUCTION}

India has one of the largest program related to immunization in the world (Govt of India, 2010). Immunizing under-five children is very costeffective approach to eliminate burden of vaccine preventable diseases in the community. It must be ensured to maintain potency of vaccines till it reaches targeted population, thus protecting them against vaccine preventable diseases and averting adverse events following immunization.

Cold chain is a system of storing and transporting vaccines at recommended temperatures from the point of manufacture to the point of use (Park K, 2013). It is sometimes referred to as the vaccine supply chain, or the immunization supply chain. A health personnel engaged in a cold chain point is expected to maintain temperature of 2-8 degree Celsius for ILR and -15 to -25 degree Celsius for deep freeze (WHO, 2015).
Immunization is one of the most important and effective interventions for reducing infant mortality and morbidity due to various vaccine preventable illnesses. It has been observed that focused efforts are required to strengthen immunization services and WHO also recommends areas like planning, financing, surveillance, staff and management, outreach activities to be monitored at district and national level (Parmar A et al, 2014). Cold chain and vaccine logistics are key drivers among them (National EVM Assessment Draft, 2013).

The present study aims to evaluate maintenance of cold chain system at primary health care centers (PHC) across Jamnagar district, logistics and observation of Mamta Day (Immunization Day) at a sub Centre or an anganwadi centre of a PHC. The observations includes knowledge and practice of health workers about immunization activities, their communication skills, training status etc. 


\section{MATERIALS AND METHODS}

There are total 31 Primary Health Centers in Jamnagar district, out of which, we decided to include $50 \%$ of primary health centers. Thus, we included 15 primary health centres, observed their cold chain, and Mamta day (Immunization day) at a sub Centre or Anganwadi centre of the selected PHC to assess the quality of immunization services. There are six Tehsils in Jamnagar district, namely Jamnagar, Lalpur, Dhrol, Jamjodhpur, Kalawad and Jodiya, we tried to include equal number of PHCs from each Tehsil to make it representative of the entire district (Table No.1)

Table 1. Selection of PHCs according to Tehsils of the district

\begin{tabular}{|l|l|l|}
\hline Sr. No. & Tehsil & No. of PHCs selected \\
\hline 1 & Jamnagar & 3 \\
\hline 2 & Lalpur & 3 \\
\hline 3 & Dhrol & 2 \\
\hline 4 & Jamjodhpur & 2 \\
\hline 5 & Kalawad & 3 \\
\hline 6 & Jodiya & 2 \\
\hline Total & 15 \\
\hline
\end{tabular}

A predesigned checklist was used to collect relevant data. The information was collected from medical officer, pharmacist and paramedical workers involved in routine immunization activities. The information included status of cold chain system their maintenance, vaccine and logistics management, vaccine storage and temperature monitoring practices, immunization waste disposal practices, record keeping etc.

Study design: It was a cross-sectional study involving rural peripheral health institutions of Jamnagar district.
Study Period: July 2018 to April 2019.

Ethical Approval: We obtained approval from institutional ethical committee before initiation of the study.

The Objective of the study was to evaluate cold chain and logistics management and maintenance at primary health centers, to assess knowledge, attitude and practices of health workers involved in immunization services, to identify discrepancies in current immunization services and cold chain system and to make recommendations to strengthen routine immunization services and cold chain management by rectifications of such discrepancies.

\section{RESULTS}

Table 2. Basic information of Cold Chain Points.

\begin{tabular}{|l|l|}
\hline Parameter & No. (\%) \\
\hline $\begin{array}{l}\text { Average Population of Cold Chain } \\
\text { point (CCP) (n=15) }\end{array}$ & $\begin{array}{l}21985 \text { (Range } \\
14000-31392)\end{array}$ \\
\hline $\begin{array}{l}\text { Average No. of Sub Centers catered per } \\
\text { CCP(n=15) }\end{array}$ & 6.46 (Range 4-9) \\
\hline $\begin{array}{l}\text { Average No. of Sessions held in a } \\
\text { month }\end{array}$ & $\begin{array}{l}25.13 \text { (Range 14- } \\
43)\end{array}$ \\
\hline $\begin{array}{l}\text { No. of PHCs with adequate quantity of } \\
\text { functional voltage stabilizers }\end{array}$ & $15(100)$ \\
\hline $\begin{array}{l}\text { No. of PHCs with adequate quantity of } \\
\text { cold boxes }\end{array}$ & $15(100)$ \\
\hline $\begin{array}{l}\text { No. of PHCs with adequate quantity of } \\
\text { vaccine carriers }\end{array}$ & $15(100)$ \\
\hline
\end{tabular}

We observed that average population per cold chain point was 21985 , with mean number of sub centers per cold chain point was 6.46. All cold chain points were connected with voltage stabilizers and had adequate vaccine carriers.

Table 3. Cold Chain Handling and maintenance practices at Cold Chain Points

\begin{tabular}{|l|l}
\hline Parameters & No.(\%) \\
ILR & $15(100)$ \\
1. Placed on a stand properly & $15(100)$ \\
2. $10 \mathrm{~cm}$ away from wall & $15(100$ \\
3. Stabilizer connected & $15(100)$ \\
4. Not exposed to direct sunlight & $15(100)$ \\
5. Things other than vaccine found & $14(93.33)$ \\
6. Functional thermometer placed inside & $15(100)$ \\
7. Temperature log book available & $15(100)$ \\
8. Temperature log book up-to date & $15(100)$ \\
9. Correct Storage of Vaccines (in Baskets and T series vaccines on the top) \\
10. Any damaged or frozen vial found in ILR & $15(100)$ \\
11. Any open vial without date/time found in ILR & $1(6.67)$ \\
12. ILR containing things other than vaccines & $0(0)$ \\
13. Vaccine diluents stored at least 24 hours in ILR before issue & $15(100)$ \\
DF & $15(100)$ \\
1. Placed on a stand properly & $15(100)$ \\
2. 10 cm away from wall & $15(100)$ \\
3. Stabilizer connected & $15(100)$ \\
4. Not exposed to direct sunlight & $10(66.67)$ \\
5. Ice packs arranged properly & $15(100)$ \\
6. Functional thermometer placed inside & $15(100)$ \\
7. Temperature log book available & $15(100)$ \\
8. Temperature log book up-to date & $0(0)$ \\
9. Any Vaccine found in Deep Freeze &
\end{tabular}


All ILRs and DFs were places in cold chain room in cold chain points as per standard guidelines. Temperature log books were available and were up to date till the day of visit. Vaccine carriers were properly stored in 11 cold chain points out of 15 .

Table 4. Knowledge and Practice of cold chain handler at Cold chain Point.

\begin{tabular}{|c|c|}
\hline Parameter & No. $(\%)$ \\
\hline \multicolumn{2}{|l|}{ Medical Officer } \\
\hline Full time appointment & $11(73.33)$ \\
\hline Deputation & $4(26.67)$ \\
\hline Trained for latest immunization module & $12(80.00)$ \\
\hline $\begin{array}{l}\text { Disposal of vaccine wastage by authorized } \\
\text { bio-waste agency }\end{array}$ & $15(100)$ \\
\hline $\begin{array}{l}\text { Return of open vials from session with } \\
\text { report same day }\end{array}$ & $15(100)$ \\
\hline \multicolumn{2}{|l|}{ Vaccine delivery to session site } \\
\hline ANM & $2(13.33)$ \\
\hline AVD & $11(73.34)$ \\
\hline Both & $2(13.33)$ \\
\hline $\begin{array}{l}\text { Any recent breakdown of cold chain in last } \\
3 \text { months }\end{array}$ & $4(26.67)$ \\
\hline $\begin{array}{l}\text { Knowledge about whom to contact in case } \\
\text { of cold chain breakdown }\end{array}$ & $15(100)$ \\
\hline $\begin{array}{l}\text { Visits by higher health officials in last } 3 \\
\text { months }\end{array}$ & $13(86.67)$ \\
\hline \multicolumn{2}{|l|}{ Pharmacist } \\
\hline Full time appointment & $11(73.34)$ \\
\hline Deputation & $4(26.67)$ \\
\hline Trained for latest immunization module & $12(80.00)$ \\
\hline $\begin{array}{l}\begin{array}{l}\text { Correct demonstration of ice pack } \\
\text { conditioning }\end{array} \\
\end{array}$ & $15(100)$ \\
\hline $\begin{array}{l}\text { Availability of vaccine stock and issue } \\
\text { register }\end{array}$ & $15(100)$ \\
\hline $\begin{array}{l}\text { Upto date maintenance of vaccine stock and } \\
\text { issue register }\end{array}$ & $14(93.33)$ \\
\hline $\begin{array}{l}\text { Twice daily recording of temperature in log } \\
\text { book of ILR/DF }\end{array}$ & $15(100)$ \\
\hline $\begin{array}{l}\text { Sufficient supply of vaccine and related } \\
\text { stocks from district }\end{array}$ & $15(100)$ \\
\hline $\begin{array}{l}\text { Correct knowledge about freeze sensitive } \\
\text { vaccines }\end{array}$ & $15(100)$ \\
\hline $\begin{array}{l}\text { Knowledge about whom to contact in case } \\
\text { of cold chain breakdown }\end{array}$ & $15(100)$ \\
\hline $\begin{array}{l}\text { Preservation of BCG/MR vials returned } \\
\text { from the session in separate VC for } 24 \\
\text { hours }\end{array}$ & $15(100)$ \\
\hline
\end{tabular}

\section{DISCUSSION}

Childhood immunization is very cost effective approach for prevention and control of vaccine preventable diseases and it can only be achieved if we can ensure sero-conversion of all vaccinated children in our community. The seroconversion in children depends on many factors, internal and external. The external factors are related to maintenance of cold chain and effective vaccine management at primary health center level in rural areas and urban health center level in urban areas. Practicing small things in vaccine management like FIFO (first in first out), FEFO (first expiry first out), avoiding unnecessary opening of vaccine vials, knowledge of correct timing of vaccination (neither too late nor too early) can make a big difference in sero-conversion among immunized children.
The present study found overall adequate infrastructure and satisfactory ongoing immunization activities in rural areas of the district. All of visited facilities had functional thermometers inside cold chain equipment and twice daily recording of temperature. In a study by AIIMS Patna, functional thermometers were placed inside cold chain equipment in only $28.6 \%$ of health centers, and twice daily temperature recording was also observed in $78.6 \%$ of cold chain points (Pandey S et al, 2018). A study conducted by Naik et al in Surat city observed that twice daily temperature recording was present in all cold chain points (Naik AK et al,2013). In a study in Delhi, the twice daily temperature recording activities were observed in only $72 \%$ of facilities (Sachdeva $\mathrm{S}$ et al, 2010). According to a study conducted in Chandigarh, 98\% temperature charts were updated in all cold chain equipment (Goel NK et al,2005). A study conducted in Jamnagar observed that temperature logbooks weren't properly maintained in more than half of Primary health centers (Sanghavi MM et al, 2013).

Table 5. Observation of Mamta (Immunization) Day
\begin{tabular}{|l|l|}
\hline Parameter & No. $(\%)$ \\
\hline Banner/Poster displayed at session site & $11(73.33)$ \\
\hline Due list of beneficiaries available & $11(73.33)$ \\
\hline $\begin{array}{l}\text { Correct knowledge of ANM about open vial } \\
\text { policy practice for BCG and MR vaccine }\end{array}$ & $15(100)$ \\
\hline $\begin{array}{l}\text { Correct knowledge of ANM about usage of } \\
\text { Vitamin-A bottle after opening it. }\end{array}$ & $9(60.00)$ \\
\hline $\begin{array}{l}\text { Correct knowledge about conditioning of ice } \\
\text { pack }\end{array}$ & $15(100)$ \\
\hline $\begin{array}{l}\text { No. of session with vaccine vials without } \\
\text { date/time written on it }\end{array}$ & $2(13.33)$ \\
\hline All four key messages answered or practiced & $12(80.00)$ \\
\hline $\begin{array}{l}\text { Correct segregation and disposal of } \\
\text { immunization waste }\end{array}$ & $15(100)$ \\
\hline $\begin{array}{l}\text { Correct knowledge of ANM for following } \\
\text { vaccines to be given at a particular age of a } \\
\text { child }\end{array}$ & \\
\hline BCG & $13(86.67)$ \\
\hline Pentavalent & $14(93.33)$ \\
\hline OPV & $14(93.33)$ \\
\hline IPV & $11(73.33)$ \\
\hline MR & $6(40.00)$ \\
\hline DPT & $9(60.00)$ \\
\hline Hepatitis B & \\
\hline
\end{tabular}

In current study, vaccine were correctly stored in ILR according to prescribed guidelines, no open vials found without mentioning of date and time. A study in Jamnagar revealed similar findings and observed that about $92.86 \%$ of facilities had correct storage of vaccines (Sanghavi MM et al, 2013).

Our study revealed that all facilities had their cold chain equipment (ILR and DF) placed in cold chain room as per standard guidelines. Similar findings were observd in a study carried out in same city (Jamnagar), where all CCPs had cold chain equipment placed as per guidelines (Sanghavi MM et al, 2013) Mallik S et al observed that in only half of CCPs, these equipment were placed $10 \mathrm{~cm}$ away from the wall and in one fourth of them, equipment 
were kept on wooden platform (Mallik $\mathrm{S}$ et al, 2011).

Ice packs should be in a criss-cross pattern in deep freeze for proper freezing of icepacks. A study in Jamnagar in 2018 showed that criss cross pattern of icepacks was observed in $76.7 \%$ of total deep freezes (Patel $\mathrm{N}$ et al,2018). Training of cold chain handlers is also a vital component in cold chain management. Our study found that $80 \%$ of cold chain handlers were trained in latest cold chain module. In a study conducted in Chhattisgarh, in $98 \%$ of cold chain points, cold chain handlers were trained in latest cold chain module (Mendhe $\mathrm{H}$ et al, 2018).

Updated due list of expected beneficiaries which was very essential component, was missing in about one-fourth of session sites in this study. This might lead to more left outs and drop outs from the immunization program. A study in Baroda revealed that due list of not available in almost all session sites (Parmar A et al, 2014). In a study conducted in Bhavnagar also revealed that no sessions shared list of children due for vaccination on Mamta day and no active tracking of dropouts using due list of beneficiaries (Kotecha I et al, 2012).

\section{CONCLUSION}

The study findings suggest that most of the Cold chain points scored very good in parameters like available updated micro-plan, adequate space for icepack conditioning and disposal of immunization waste properly indicating that the facilities were keeping pace with the recent updates and good practices. The availability of trained and skilled manpower was reflected from the findings such as $\mathrm{VCCH}$ trained in latest $\mathrm{VCCH}$ module, they knew what to do in case the CCP break down and they also knew about icepack conditioning.

The overall impression comes out that most CCPs in both districts are doing good enough, though in some of the parameters the CCPs are lagging behind the expected quality, there is scope of further improvement in all the parameters by means of ongoing project of strengthening of Supportive Supervision of Routine Immunization in both the districts.

\section{RECOMMENDATIONS}

Vaccine cold chain handlers should continue following standard operating protocols for cold chain maintenance which would help to maintain the vaccine effective and potent.

Supportive supervision of routine immunization services should be continued at primary care level by Medical officers and district officials with refresher trainings of vaccine and cold chain handlers at regular intervals to stay updated about introduction of newer vaccines or guidelines. The vacant posts of cold chain handlers should be filled at the earliest to ease extra burden on them.

\section{ACKNOWLEDGEMENT}

We are thankful to Dean, M P Shah Government Medical College, Jamnagar and Chairman, MultiDisciplinary Research Unit who provided technical and financial support for this study.

\section{CONFLICT Of INTERESTS: Nil}

FINANCIAL SUPPORT: We received financial support from Multi-Disciplinary Research Unit, M P Shah Government Medical College, Jamnagar, Gujarat, India.

\section{REFERENCE}

Goel, N. K., Swami, H. M., \& Bhatia, S. P. (2004). Evaluation of cold chain system in Chandigarh during PPI campaign 20012002. Indian journal of public health, 48(4), 200-204.

Kotecha, I., \& Singh, M. P. (2012). Process evaluation of health and nutrition day (Mamta day) in urban slum areas of Bhavnagar municipal corporation. Natl J Integr Res Med, 3(1), 111-4.

Mallik, S., Mandal, P. K., Chatterjee, C., Ghosh, P., Manna, N., Chakrabarty, D. \& Dasgupta, S. (2011). Assessing cold chain status in a metro city of India: an intervention study. African health sciences, 11(1): 128-133.

Mendhe, H., Makade, K., Bhawanani, D., David, R., Kamble, N., Singh, D., \& Dengani, M. (2018). Cold chain maintenance in Rajnandgaon and Bilaspur districts of Chhattisgarh: A process evaluation. Journal of family medicine and primary care, 7(6), 1510.

Ministry of Health and Family Welfare; 2010.[Last accessed on 2012 Feb 17]. Govt. of India. Handbook for vaccine and cold chain handlers.

Naik, A. K., Rupani, M. P., \& Bansal, R. K. (2013). Evaluation of vaccine cold chain in urban health centers of municipal corporation of Surat city, Western India. International journal of preventive medicine, 4(12), 1395.

National Effective Vaccine Management Assessment, India. 2013. Draft V3-5:9. Available from

Pandey, S., Singh, C. M., Ranjan, A., Kumar, Y., Kumar, P., \& Agarwal, N. (2018). Assessment of Cold Chain System for Routine Immunization of Primary Health centres of the Bhojpur district of Bihar. Indian Journal of Community Health, 30(2).

Park K., (2013). Park's Textbook of Preventive and Social Medicine. 22 $2^{\text {nd }}$ ed. Jabalpur: Banarasidas Bhanot Publisher..p.813. 
Parmar, A., Parmar, N., Pandya, C., \& Mazumdar, V. S. (2014). Process evaluation of routine immunization (RI) and growth monitoring services during mamta day (village health and nutrition day) in sinor block of Vadodara district, Gujarat, India. Natl $J$ Community Med, 5(4), 378-82.

Patel, N., Unadkaat, S. V., Sarkar, A., Rathod, M., \& Parmar, D. V. (2018). Assessment of cold chain maintenance for routine immunization in Jamnagar district, Gujarat. Int J Med Sci Public Health, 7, 1-5.
Sachdeva, S. (2010). Status of vaccine cold chain maintenance in Delhi, India. Ind J Medical Microbiology, 28(2): 184-185

Sanghavi, M. M. (2013). Assessment of routine immunization program at primary health centre level in Jamnagar district. Nat $\mathrm{J}$ Med Res, 3(4), 319-323.

World Health Organization, \& World Health Organization. Department of Immunization. (2015). Immunization in Practice: A practical guide for health staff. World Health Organization. 